\title{
Caballerocotyla lenti n. sp., a Capsalid Monogenean from Auxis thazard (Scombridae) from off the Southeastern Coast of Brazil
}

\author{
Cristina D Mogrovejo, Cláudia P Santos*/+
}

Instituto de Ciências Biológicas e Ambientais, Universidade Santa Úrsula, Rio de Janeiro, RJ, Brasil *Laboratório de Avaliação e Proteção Ambiental, Departamento de Biologia, Instituto Oswaldo Cruz-Fiocruz, Av. Brasil 4365, 21045-900 Rio de Janeiro, RJ, Brasil

Caballerocotyla lenti n. sp. (Monogenea: Capsalidae), recovered from the gills of Auxis thazard (Lacépède) captured off the coast of Rio de Janeiro, Brazil, is described using light and scanning electron microscopy. The new species is characterized by: a tegument with 2-5 rows of dorso-marginal, unicuspid spines; 53-54 round testes; a constricted pharynx with numerous papillae on its border; and a haptor with a plicate marginal border, a central polygonal area and seven complete septa. C. manteri (Price, 1951) and C. gouri Chauhan, 1953 sensu Murugesh (1995) are figured and commented upon.

Key words: Monogenea - Caballerocotyla lenti n. sp. - Auxis thazard - fish - Brazil

Among the Capsalidae, species of Caballerocotyla Price, 1960 are characterized by the position of the numerous testes, which are confined to the intercaecal area, and a pharynx with a typical constriction. The genus contains 26 species mainly reported from scombrid fishes throughout the world, in both tropical and subtropical areas.

Auxis thazard (Lacépède, 1800) is a pelagic, migratory, oceanic fish, that inhabits hot waters in all the tropical and subtropical seas, being commercially explored fresh, cured, tinned or as bait for great tunas fisheries. During a parasitological survey of this scombrid specimens of Caballerocotyla were encountered on the gills. These worms are described below as a new species, based on studies using both light and electron microscopy.

\section{MATERIALS AND METHODS}

From January to December, 2000, a total of 110 fishes were obtained from fishermen and fish markets at Rio de Janeiro, Brazil, and examined for parasites. Some fish were frozen prior to examination. Some of the worms recovered were fixed and stored in 70\% alcohol, stained in Mayer's paracarmine, dehydrated in an ethanol series, cleared in creosote, mounted in Canada balsam and studied using differential interference microscopy. The scale bars are presented in millimeters as the range, with the mean in parentheses. Illustrations were made with the aid of a drawing tube. For scanning electron microscopy (SEM), freshly collected parasites were fixed in a solution of $2.5 \%$ glutaraldehyde in $0.2 \mathrm{M}$ cacodylate buffer ( $\mathrm{pH} 8.3$ ), $4 \%$ paraformaldehyde in distilled water and washed in PBS. Specimens were post-fixed in $1 \%$ osmiun tetroxide in 0.1 M cacodylate buffer, dehydrated through a graded etha-

Financial support: Faperj/Mackpesquisa

${ }^{+}$Corresponding author. Fax: +55-21-2598.4378. E-mail: cpsantos@ioc.fiocruz.br

Received 3 April 2002

Accepted 31 July 2002 nol series, critically point dried and sputter-coated with gold. They were examined using a JSM-8500 scanning electron microscope at an accelerating voltage of $15 \mathrm{kV}$.

Paratypes of Caballerocotyla manteri (Price, 1951) from the US National Parasite Collection (no. 37229) and a specimen of C. gouri (Chauhan 1953) from the British Museum (Natural History) Collection at The Natural History Museum, London (BMNH) (1993.5.18.2) were examined. Type and voucher specimens of the present material are deposited in the Helminthological Collection of the Instituto Oswaldo Cruz, Brazil (CHIOC).

\section{RESULTS}

Family Capsalidae Price, 1939

Caballerocotyla Price, 1960

Caballerocotyla lenti n.sp.

Description (Figs 1-7): based on 6 specimens. Body elongate, 0.520-4.92 (2.31) long; maximum width 0.224-2.310 (1.13). Haptor smaller than maximum width of body. Tegument with 2-5 rows of dorso-marginal unicuspid spines 0.023-0.025 (0.024) long. Anterior region bears 2 ellipsoid suckers, $0.076-0.431 \times 0.142-0.585(0.26 \times 0.29)$, and 2 pairs of eye-spots (Fig. 1). Haptor 0.494-1.503 × 0.437-1.478 $(0.793 \times 0.830)$ surrounded by delicate, plicate marginal border. Internal surface of disc divided around central locus into 7 complete, lateral loci. One pair of anchors, $0.029-0.323(0.290)$ long. Fourteen marginal hooks 0.0110.013 (0.013) long. Mouth ventral, situated in between and in plane of posterior region of anterior suckers; pharynx $0.066-0.674 \times 0.046-0.674(0.30 \times 0.29)$ in maximum width, constricted into 2 regions; oesophagus short; caeca with numerous diverticula, united at posterior end of body. Testes 52-54 in number, entire and intercaecal. Cirrus-sac narrow. Genital pore lateral, just posterior to left anterior sucker. Ovary globular, posterior to pharynx, intercaecal, $0.032-0.173 \times 0.064-0.228(0.101 \times 0.154)$. Oviduct short, passes sinistraly towards base of oötype. Two vitelloducts join vitelline reservoir, $0.034-0.136 \times 0.062-0.132(0.082 \times$ $0.107)$. Vitellarium dendritic, extends from cephalic lobe to haptor in lateral fields of body. Seminal receptacle globular, to left of vitelline reservoir, links to narrow vagina. 


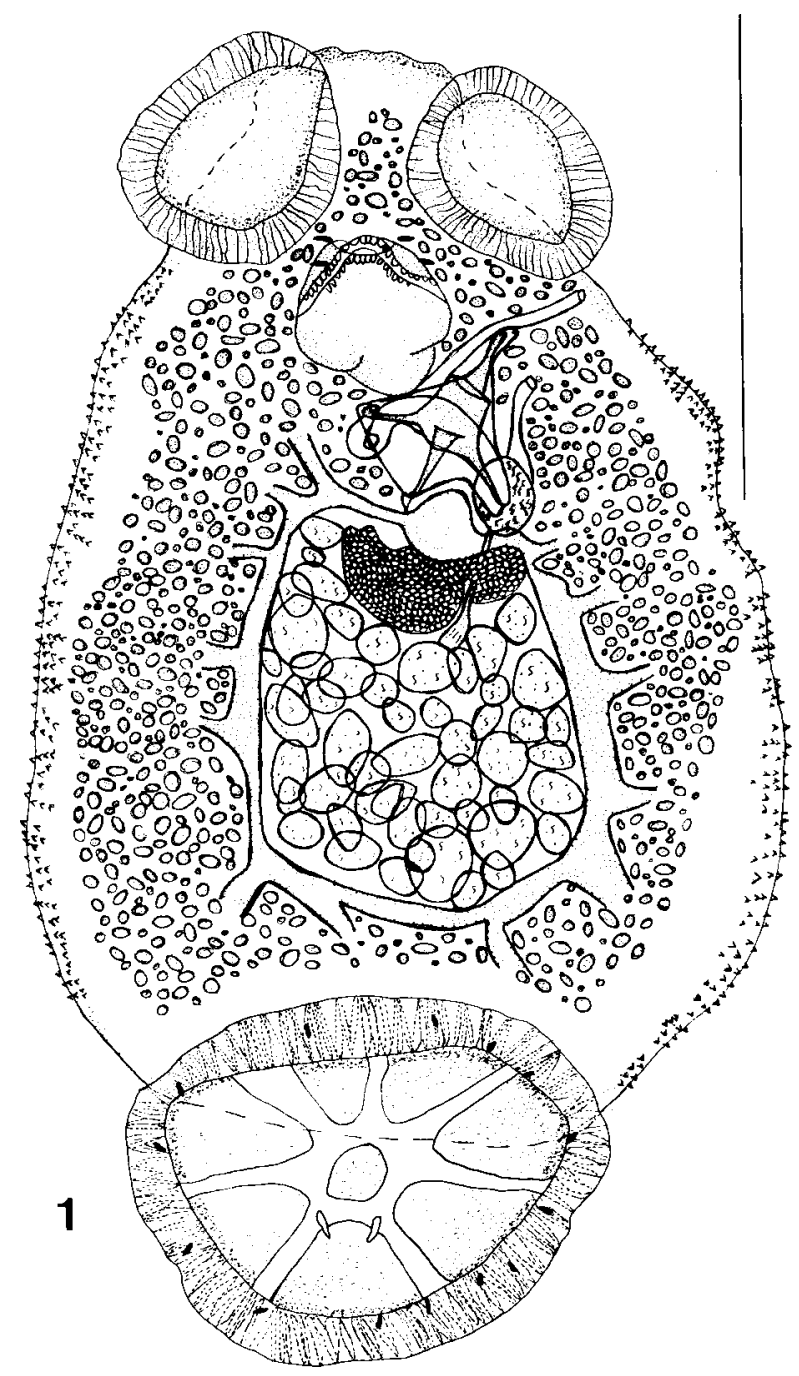

Caballerocotyla lenti n. sp. - Fig. 1: general view. Scale bar $=0.6 \mathrm{~mm}$.

Vaginal pore at 0.21-0.69 (0.52) from genital pore. Eggs $0.073-0.082 \times 0.066-0.082(0.080 \times 0.077)$, with 4 filaments 0.046-0.103 (0.074) long.

$S E M$ : body elongate; antero-ventral region with smooth, cephalic lobe and round anterior suckers; posterior region with septate, disc-like haptor (Fig. 2). Numerous papillae surround triangular margin of pharynx within mouth (Fig. 3). Lateral margins of body with 2-5 dorsomarginal rows of unicuspid spines (Fig. 4). Haptor divided by 7 complete septa which rise from central polygonal area and extend to plicate marginal border (Fig. 5). Tips of anchors rise from base of central polygonal area; equidistant marginal hooks surround inner part of marginal border (Fig. 6).

Type-host: Auxis thazard (Lacépède) (Scombridae)

Type-locality: State of Rio de Janeiro, Brazil (22 ${ }^{\circ} 55^{\prime} \mathrm{S}$, $40^{\circ} 18^{\prime} \mathrm{W}$ )

Habitat: gills

Infection: prevalence $12.73 \%$; mean intensity 1.07 ; mean abundance 0.14
Type-material: Holotype CHIOC 34938; paratypes CHIOC 34939, 34940 and 34941

Etymology: the new species is named for Prof. Herman Lent, a distinguished Brazilian parasitologist.

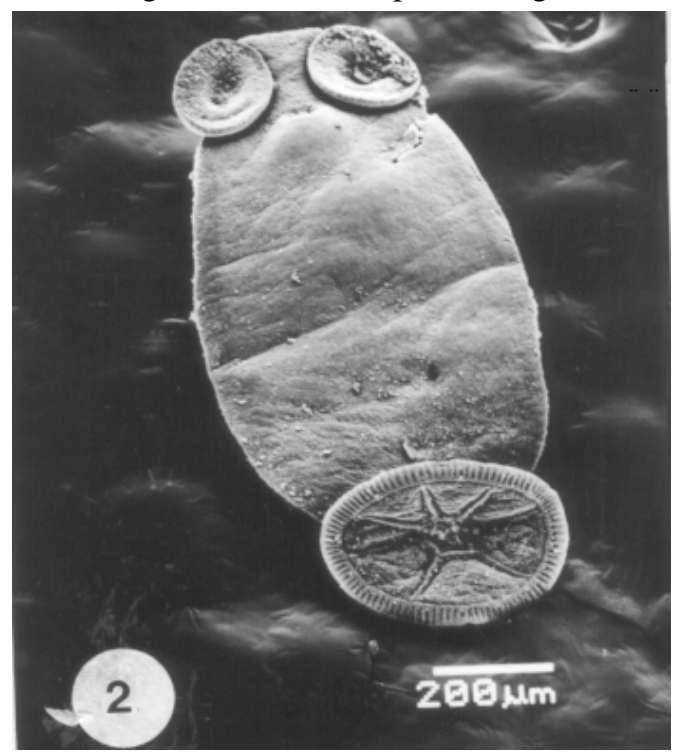

Caballerocotyla lenti $\mathrm{n}$. sp. - Fig. 2: general view of body with anterior suckers and posterior haptor with septa.

\section{Caballerocotyla manteri (Price, 1951) Price, 1960}

Redescription (Fig. 7): body elongate, 2.35 long $\times 1.57$ wide. Tegument with 1 row of dorso-marginal unicuspid spines. Anterior region bears 2 ellipsoid suckers, $0.39 \times$ 0.42 , and 2 pairs of eye-spots. Haptor $0.85 \times 0.88$. Anchors and marginal hooks (14) not measured. Mouth ventral, pharynx $0.36 \times 0.32$ in maximum width, constricted into 2 regions. Testes 35 in number, entire and intercaecal. Cirrus-sac narrow. Genital pore lateral. Ovary globular, intercaecal $0.17 \times 0.26$. Vitelline reservoir $0.11 \times 0.18$. Eggs not observed.

Type-host: Euthynnus alletterata (Rafinesque, 1810) (Scombridae)

Type-locality: Tortugas, Florida

Habitat: gills

Material: paratype USNM Reg. no. 37229

$$
\begin{gathered}
\text { Caballerocotyla gouri (Chauhan, 1953) } \\
\text { sensu Muruguesh (1995) }
\end{gathered}
$$

Redescription (Fig. 8): body elongate, 8.2 long, 5.8 wide. Tegument with 5-6 rows of dorso-marginal unicuspid spines. Anterior region bears 2 suckers, $0.86 \times 0.83$. Haptor $2.6 \times 2.4$. Anchors and marginal hooks (14) not measured. Pharynx $1.00 \times 1.06$ in maximum width. Testes $>100$ in number, lobed and intercaecal. Cirrus-sac narrow. Genital pore lateral. Ovary lobed, intercaecal $0.66 \times 0.75$. Vitelline reservoir $0.20 \times 0.30$. Eggs not observed.

Type-host: unspecified scombrid

Type-locality: Bay of Bengal

Habitat: gills

Material: voucher BMNH Reg. no. 1993.5.18.2 

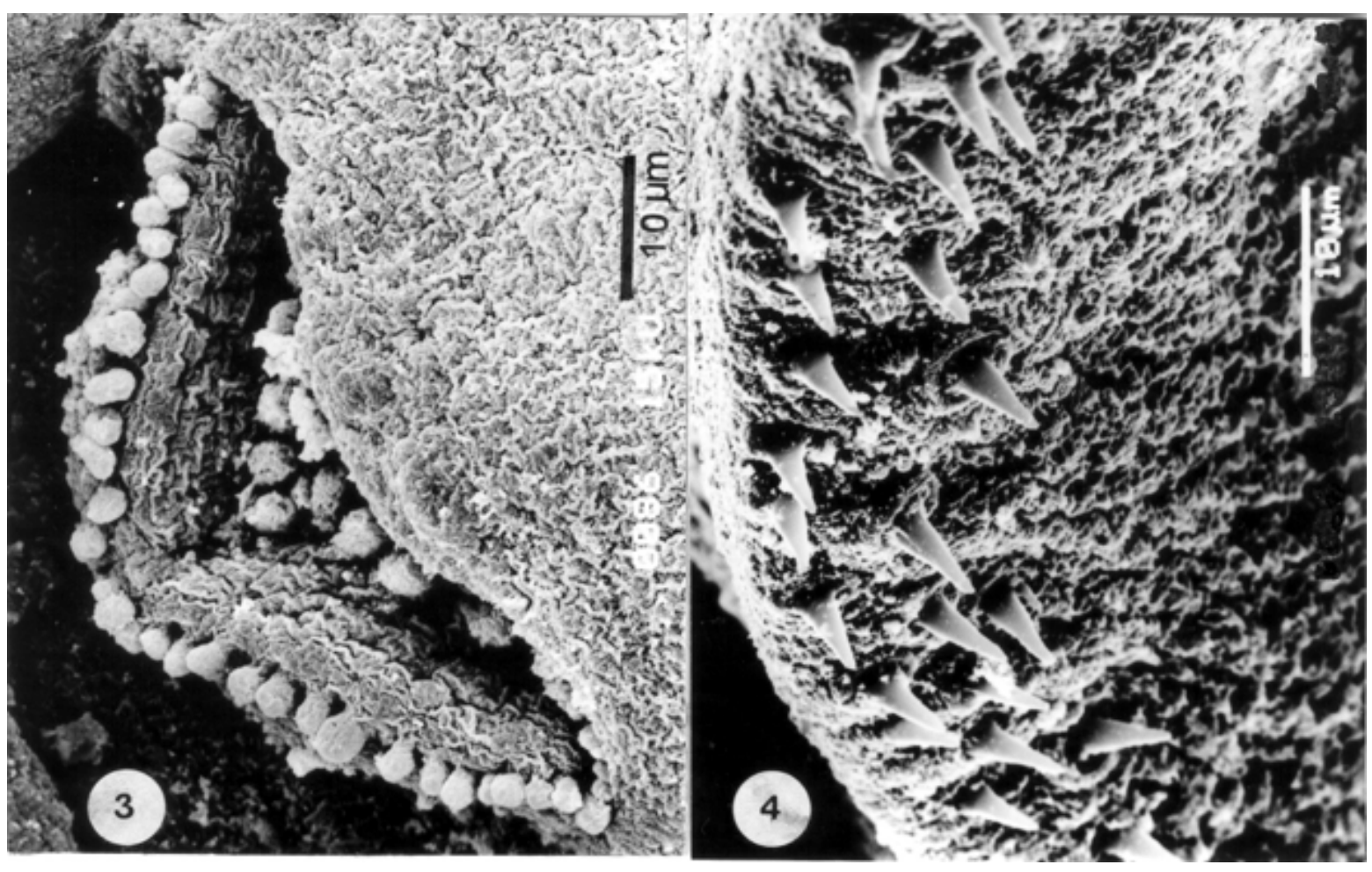

Caballerocotyla lenti n. sp. Fig. 3: numerous papillae surround triangular margin of pharynx within mouth. Fig. 4: lateral margins of body with 2-5 dorso-marginal rows of unicuspid spines (SEM).

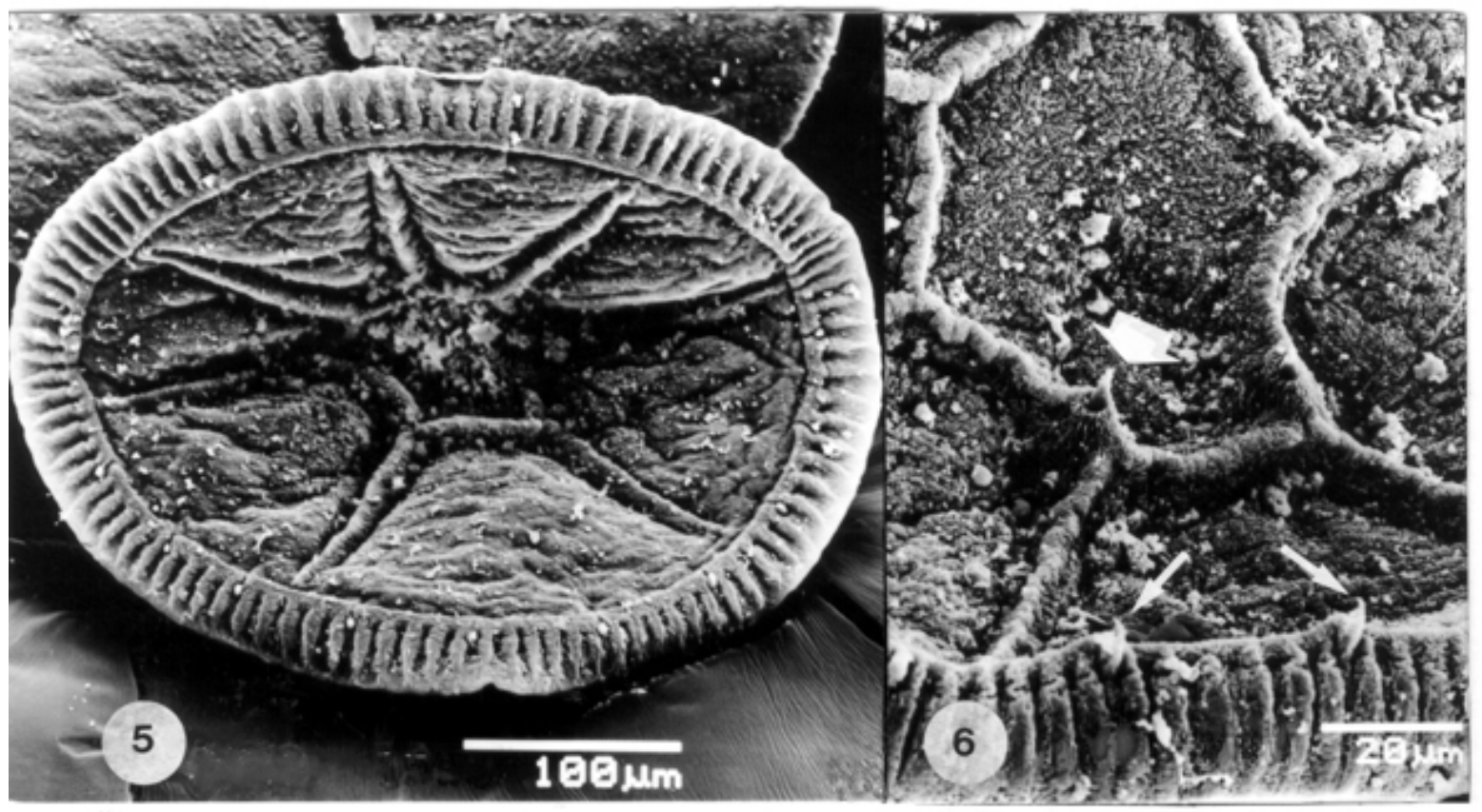

Caballerocotyla lenti n. sp. - Fig. 5: haptor with 7 complete septa rising from central polygonal area, and extending to the plicate marginal border. Fig. 6: tip of anchor (large arrow) rising from base of central polygonal area and marginal hooks on the inner part of marginal border (small arrows) (SEM).

\section{DISCUSSION}

Species of Caballerocotyla Price, 1960, revised by Lamothe-Argumedo (1997), are characterized by the presence of numerous intercaecal testes, a haptor divided by septa and a constricted pharynx. Even though in this revision Lamothe-Argumedo indicated that, when body spines are present, they have five or six cusps, they do in fact range from single to multi-cusped. 


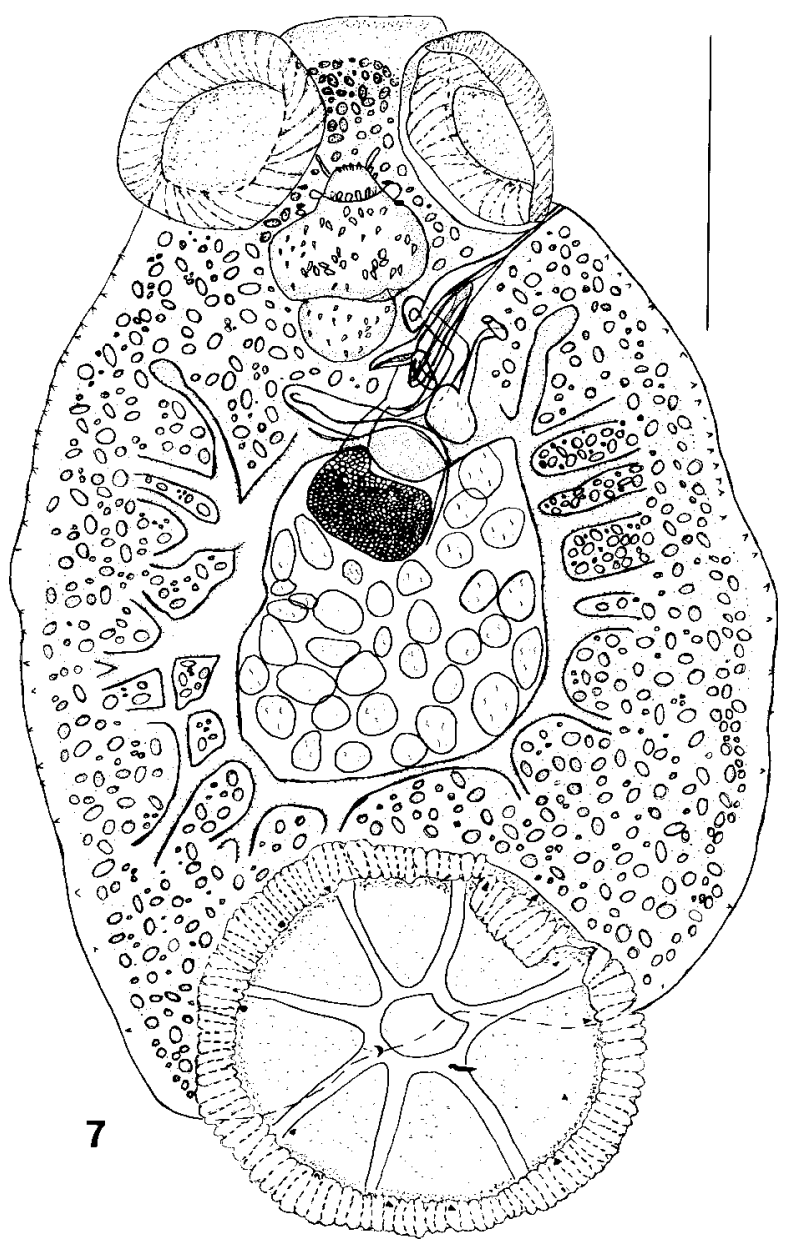

Caballerocotyla manteri - Fig. 7: general view of paratype USNPC -37229 with a single row of dorso-marginal unicuspid spines and a reduced number of round testes. Scale bar $=0.6 \mathrm{~mm}$.

The species of the genus include C. biparasitica (Goto 1894) Price 1960, C. andhraensis (Raju \& Rao, 1980) Lamothe-Argumedo, 1997, C. abdijani Bussieras \& Laurencin, 1970, C. albsmithi Dollfus, 1962, C. australis Oliva, 1986, C. caballeroi (Winter, 1955) Price, 1960, C. chilensis Pillai \& Pillai, 1976, C. foliacea (Goto, 1894) Price, 1960, C. gotoi (Yamaguti, 1968) Oliva, 1986, C. gouri (Chauhan, 1951) Price, 1960, C. gregalis Wagner \& Carter, 1967, C. katsuwomis (Ishii, 1936) Price, 1960, C. katuo (Iwata, 1990) Lamothe-Argumedo, 1997, C. klawei Stunkard, 1962, C. magronum (Ishii, 1946) Price, 1960, C. manteri (Price, 1951) Price, 1960, C. manteri affinis Mamev, 1968, C. neothunni (Yamaguti, 1968) Oliva, 1986, C. notosinensis Mamaev, 1968, C. nozawae (Goto, 1894) Egorova, 1989, C. paucispinosa Mamaev, 1968, C. pelamidys (Taschenberg, 1878) Price, 1960, C. phillippina Velázquez, 1982, C. pseudomagronum Bussieras, 1972, C. thazardi Pilai \& Pilai, 1976 and C. verrucosa Bussieras, 1972.

The species of the genus reported from Auxis thazard include C. manteri Price, 1951 from the Pacific (Williams \& Bunkley Williams, 1996), C. manteri affinis Mamaev,
1968 and Caballerocotyla sp. from South China Sea (Mamaev, 1968), C. thazardi Pillai \& Pillai, 1976 from Arabian Sea, C. andhraensis Raju \& Rao, 1980 from Bay of Bengal, India and C. gouri (Chauhan, 1953) reported by Murugesh (1995) from both the Arabian Sea and Bay of Bengal, India.

C. manteri Price, 1951, first described from Euthynnus alletterata of Florida is similar to C. manteri affinis, also recorded from $E$. affinis. The types of $C$. manteri affinis could not be examined, but study of the paratype of $C$. manteri (USNM Reg. no. 37229) confirmed the presence of a single row of dorso-marginal unicuspid spines and a reduced number of testes (35) (Fig. 7). The types of $C$. thazardi could also not be obtained, but, based on the original description, this species also differs from $C$. lenti n. sp. in the presence of a single row of dorso-marginal unicuspid spines.

Caballerocotyla sp. of Mamaev (1968) differs from C. lenti $\mathrm{n}$. sp. in the presence of dorso-marginal spines with eight or nine cusps.

Chauhan (1953) described C. gouri from E. alletterata (= Thynnus thunina) as having a single row of dorsomarginal spines with five or six cusps each, as well as a globular ovary and testes. Murugesh (1995) subsequently reported this species from E. affinis, Thunnus tonggol, Sarda orientalis and A. thazard, considering $C$.

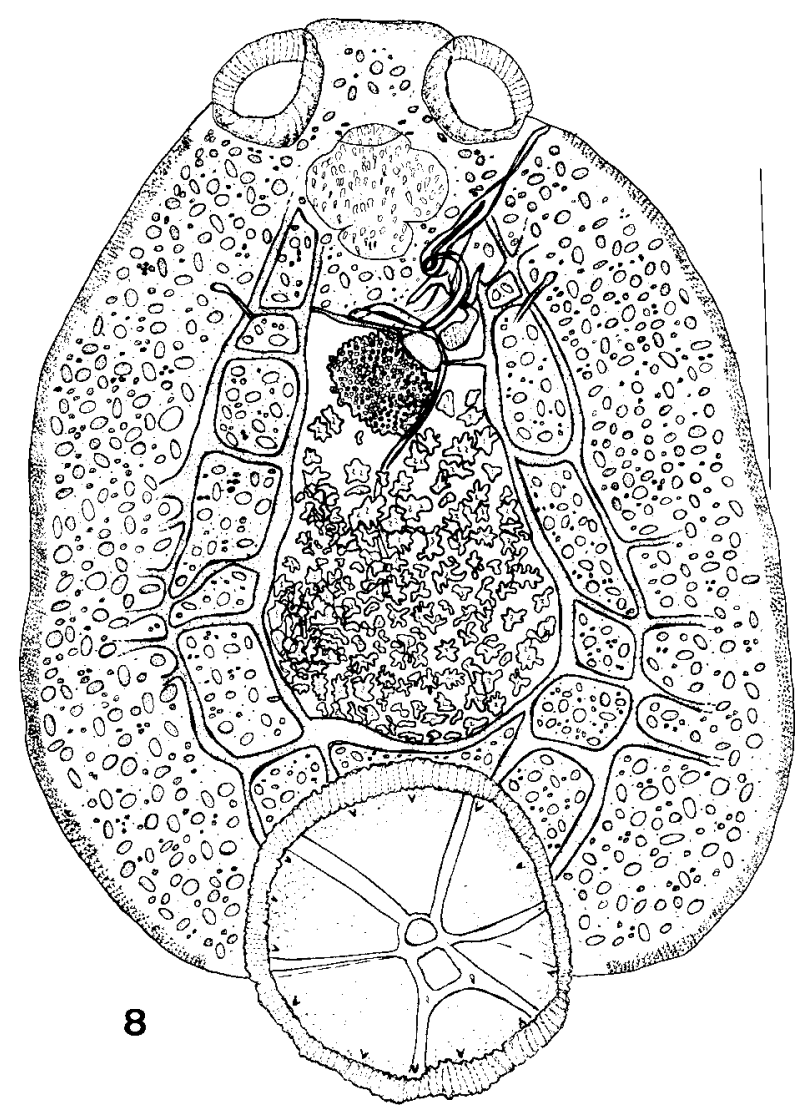

Caballerocotyla gouri - Fig. 8: general view of specimen BMNH1993.5.18.2 with 5-6 rows of unicuspid spines and a lobed ovary and testes. Scale bar $=2.4 \mathrm{~mm}$. 
andhraensis a synonym of $C$. gouri. Nevertheless, while examining the specimens of $C$. gouri studied by Muruguesh (1995) (BMNH Reg. no. 1993.5.18.2) (Fig. 8), we found five or six rows of unicuspid spines and a lobed ovary and testes, differing from both $C$. gouri and $C$. andhraensis which have two to four rows of unicuspid spines and globular testes. The synonymy $C$. gouri and C. andhraensis is therefore, not considered here as valid.

Therefore, C. gouri of Chauhan (1953) differs from $C$. lenti $\mathrm{n}$. sp. in the numbers of rows and spine cusps and by the number and arrangement of haptoral septa. $C$. andhraensis from the Bay of Bengal is closer to the new species in relation to its body measurements and the presence of two to four rows of dorso-marginal unicuspid spines. Although the types could not be found, this species differs from $C$. lenti $\mathrm{n}$. sp. by having a body which tapers posteriorly, dorso-marginal spines diminishing in number and size towards the posterior end of body, discontinuous haptoral septa, the position of the anchors in the posterior septum and a median septum with a tendency to subdivide.

Considering all the other species of the genus, those which most closely resembles $C$. lenti n. sp. are C. chilensis Pillai \& Pillai, 1976 from Sarda chilensis off the Kerala coast and C. notosinense Mamaev 1968 from Euthynnus affinis in the South China Sea, both with two to four rows of dorso-marginal unicuspid spines. However, they differ from the new species in having larger body, anchors and marginal hooks. The remaining species can be readily differentiated by the size, shape and number of spines and cusps, the size of the anchors and the number of testes.

C. lenti $\mathrm{n}$. sp. represents the first species of the genus to be reported off the coast of Brazil.

\section{ACKNOWLEDGEMENTS}

To Dr David Gibson of The Natural History Museum, London for help from the Host-Parasite Data-Base of the Parasitic Worms Division, for providing literature and the loan of specimens. To Chaparral Ltda for donation of fresh fishes and to Dr Marlene Benchimol from the Laboratory of Electronic Microscopy of University Santa Úrsula, for technical support.

\section{REFERENCES}

Chauhan BS 1953. Trematodes from Indian marine fishes. Part VII: On monogenetic parasites of the family Capsalidae Baird, 1853 (Capsaloidea) from Indian region, with description of a new species of the genus Capsala Bosc 1811. Rec Indian Mus 49: 45-51.

Lamothe-Argumedo R 1997. Nuevo arreglo taxonómico de la subfamilia Capsalinae (Monogenea: Capsalinae), clave para los géneros y dos combinaciones nuevas. An Inst Biol Univ Nac Autón Mexico Ser Zool 68: 207-223.

Murugesh M 1995. Monogenetic trematodes from scombrid fishes of the Visakhapatnam coast, Bay of Bengal. $J$ Nat Hist 29: 1-26.

Mamaev YL 1968. [Helminths of tuna fish in the South China Sea.] In KI Skrjabin, YL Mamaev EAS (eds), [Helminths of Animals of the Pacific Ocean], Moscow, p. 5-27.

Williams Jr EH, Bunkley Williams L 1996. Parasites of Offshore Big Game Fishes of Puerto Rico and the Western Atlantic, Puerto Rico Department of Natural and Environmental Resources, San Juan, 382 pp. 